\title{
Comparison of open and laparoscopic appendectomy in uncomplicated appendicitis: a prospective randomized clinical trial
}

\author{
Komplike olmayan apandisitlerde açık ve laparoskopik apendektominin \\ karşılaştırılması: Bir prospektif randomize klinik çalışma
}

\author{
Ali KOCATAŞ, ${ }^{1}$ Murat GÖNENÇ, ${ }^{1}$ Mehmet Abdussamet BOZKURT, ${ }^{2}$ \\ Mehmet KARABULUT, ${ }^{1}$ Eyup GEMICI, ${ }^{1}$ Halil ALIŞ ${ }^{1}$
}

\section{BACKGROUND}

In the treatment of a subset of patients with uncomplicated appendicitis, no surgical method has been clearly established as superior.

\section{METHODS}

The present study was a prospective randomized clinical trial. Patients diagnosed with acute appendicitis were recruited for the study. Patients with a preoperative diagnosis of complicated appendicitis were excluded. The patients were randomly divided into two groups: a laparoscopic appendectomy group and an open appendectomy group. The primary outcome measure was the rate of postoperative septic complications. Secondary outcome measures were the length of hospital stay, postoperative pain score, and quality of life score.

\section{RESULTS}

Ninety-six patients were included in the study, 50 in the laparoscopic appendectomy group and 46 in the open appendectomy group. There were no significant differences between the two groups in terms of the rates of postoperative septic complications, hospital stay lengths, postoperative pain scores, or quality of life scores.

\section{CONCLUSION}

The laparoscopic approach to appendectomy in patients with uncomplicated appendicitis does not offer a significant advantage over the open approach in terms of length of hospital stay, postoperative pain score, or quality of life, which are considered the major advantages of minimally invasive surgery.

Key Words: Appendicitis; laparoscopic appendectomy; open appendectomy; pain score; uncomplicated appendicitis; quality of life.

\section{AMAC}

Komplike olmayan apandisitle başvuran hastalarda herhangi bir cerrahi yöntemin diğerine üstünlüğü henüz açıkça belirlenmemiştir.

\section{GEREÇ VE YÖNTEM}

Çalışma, ileriye yönelik randomize bir klinik çalışmayd. Akut apandisit tanısı konulan hastalar çalışmaya alındi. Ameliyat öncesi olarak komplike apandisit tanısı alan hastalar çalışmanın dışında tutuldu. Hastalar iki gruba ayrıldı: Laparoskopik apendektomi grubu ve açık apendektomi grubu. Birincil sonuç ölçütü ameliyat sonrası septik komplikasyon oranıdı. İkincil sonuç ölçütleri hastanede kalış süresi, ameliyat sonrası ağrı skoru ve yaşam kalitesi skoruydu.

\section{BULGULAR}

Çalışmaya alınan 96 hastanın 50'si laparoskopik apendektomi grubu, 46'sı ise açık apendektomi grubu olarak ayrıld. Ameliyat sonrası septik komplikasyonların oranı, hastanede kalış süresi, ameliyat sonrası ağrı skoru ve yaşam kalitesi skoru açısından iki grup arasında anlamlı bir fark saptanmadi.

\section{SONUÇ}

Komplike olmayan apandisit olgularında laparoskopik yaklaşım, minimal invasif cerrahinin önemli avantajları olduğu kabul edilen hastanede kalış süresi, ameliyat sonrası ağrı skoru ve yaşam kalitesi açısından açık yaklaşıma göre önemli bir avantaj sağlamamaktadır.

Anahtar Sözcükler: Açık apendektomi; ağrı skoru; apandisit; komplike olmayan apandisit; laparoskopik apendektomi; yaşam kalitesi.

\footnotetext{
${ }^{1}$ Department of General Surgery, Dr. Sadi Konuk Training and Research Hospital, Istanbul;

${ }^{2}$ Department of General Surgery, Pervari Public Hospital, Siirt, Turkey.
}

${ }^{1}$ Dr. Sadi Konuk Eğitim ve Araștırma Hastanesi, Genel Cerrahi Kliniği, İstanbul;

${ }^{2}$ Pervari Devlet Hastanesi, Genel Cerrahi Kliniği, Siirt. 
The gold standard treatment for acute appendicitis has been open appendectomy (OA) due to its efficient outcomes ${ }^{[1]}$ In 1983, however, Semm introduced laparoscopic appendectomy (LA), which has since become increasingly popular. ${ }^{[2]}$ SAGES strongly recommends LA only for female patients of child-bearing age because the advantages of minimal invasive surgery, such as shorter length of hospital stay, better cosmetic appearance, faster recovery and return to normal activities, and less postoperative pain, are considered to be relative for appendectomy, in patients with uncomplicated appendicitis in particular. ${ }^{[1,3-6]}$

LA is not favored because of longer operative times, greater hospital costs, and most importantly, increased incidence of postoperative abscess formation. [7] However, operative times have dramatically decreased with increasing experience. Furthermore, the use of reusable laparoscopic instruments has led to a significant reduction in hospital charges. Nonetheless, increased incidence of postoperative abscess formation continues to be a major concern in spite of many studies reporting contradictory results. ${ }^{[6-9]}$

In the treatment of a subset of patients with uncomplicated appendicitis, no surgical method has been clearly established as superior. Thus, we conducted a prospective randomized clinical trial comparing OA and LA in the treatment of uncomplicated appendicitis.

\section{MATERIALS AND METHODS}

The study was designed as a prospective randomized clinical trial and was initiated after approval by the institutional review board. The inclusion criterion was preoperative diagnosis of acute appendicitis. All of the patients underwent combined clinical, radiological, and biochemical evaluations for acute appendicitis. The diagnosis was determined and the final decision for surgical treatment was made by the attending surgeon. All of the patients were given detailed information about the study and provided signed informed consent forms.

The patients were divided into two randomized groups: Group 1 underwent laparoscopic appendectomy, whereas Group 2 underwent OA. Randomization was performed using a lottery method. A resident, who had no knowledge of the preoperative data and would not be involved in the operations, was chosen to select lottery cards. Exclusion criteria were as follows: unwillingness to participate; inability to provide informed consent (mental disabilities); age younger than 15 years; pregnancy; severe sepsis or septic shock on admission; contraindication for laparoscopy; ASA III or IV; conversion to open procedure; and complicated appendicitis.

All of the operations were performed under general anesthesia. Prophylactic antibiotherapy with a single shot of cefazolin ( $1 \mathrm{~g}$, intravenous) was administered on a routine basis during the induction of anesthesia. All of the operations were performed by residents who were at least within their second year under supervision of the chief resident or the attending surgeon.

In the laparoscopic approach, a temporary Foley catheter and an orogastric tube were inserted after the induction of general anesthesia to prevent visceral injury; both were withdrawn prior to recovery from anesthesia. The patient was positioned in a $30^{\circ}$ Trendelenburg position and a $15^{\circ}$ left tilt. A Verres needle was used to create pneumoperitoneum in all patients except those who had undergone previous abdominal surgery; Hasson technique was used on the latter patients instead. A 10-mm optic trocar was inserted through an infraumbilical incision, and a $30^{\circ}$ scope was utilized in all cases. Under direct vision, a $10-\mathrm{mm}$ and a 5-mm trocar were introduced in the left lower quadrant and suprapubic region, respectively. The dissection of the mesoappendix was performed using a 5-mm or a 10-mm vessel sealing device (The LigaSureTM Vessel Sealing System, Valleylab, Boulder, CO, USA). The dissection was kept as close to the appendix as possible to reduce the bulk of the specimen so as to avoid specimen delivery problems. The appendiceal base was secured using intracorporeal knotting with $2 / 0$ silk. Either one or two knots were used based on the experience of the operating surgeon. The standard knot type used was a square knot with two turns in the first throw and one turn in the last two throws. A metal endoclip was applied to the specimen's side to prevent contamination. Following the appendectomy, the specimen was extracted from the trocar in the left lower quadrant and placed in a specimen bag. A "suction only" policy was preferred over irrigation unless there was localized pus accumulation in the pelvis. Drainage was avoided in all cases.

In the open procedure, a Rockey-Davis or McBurney incision was used for the laparotomy. The anterolateral abdominal muscles were split, and the peritoneum was incised. The mesoappendix was ligated with $2 / 0$ silk and divided. The base of the appendix was ligated with $2 / 0$ silk. A hemostat was applied to the distal side of the specimen, and the appendix was transected. The incision was closed in an anatomic fashion. Again, a "suction only" policy was preferred over irrigation unless there was localized pus accumulation in the pelvis. Drainage was similarly avoided in all cases.

All of the patients, except those who experienced nausea or vomiting, were allowed to start oral intake at the 4th postoperative hour. Tramadol $(100 \mathrm{mg}$ as needed, intravenous) was administered for the management of postoperative pain and was replaced by peroral naproxen sodium (550 mg twice a day) after the initiation of oral intake. 
The patients were followed for 30 days after surgery. All of the findings among those admitted for dressing changes and stitch removal and those readmitted for postoperative complications were recorded. A visual analog pain scale was used to compare postoperative pain at the 4 th postoperative hour and at the time of discharge. All of the patients were asked to complete to a quality of life questionnaire, specifically, the Nottingham Health Profile, at the 15th postoperative day. The Nottingham Health Profile is a validated tool that consists of 38 health-related questions which represent six dimensions of subjective health: physical mobility, pain, sleep, energy, emotional reactions, and social isolation. ${ }^{[10-12]}$ The primary outcome measure was postoperative complications, including readmissions, rehospitalizations, and reoperations. The secondary outcome measures were length of hospital stay, visual analog pain scores, and quality of life scores.

Statistical analysis was performed using NCSS 2007 Software (NCSS, Kaysville, UT, USA). Descriptive data were expressed as mean values and standard deviations. Student's t-test and Fisher's exact test were used to evaluate proportional data and qualitative data, respectively, for intergroup differences. A $p$ value less than 0.05 was considered statistically significant.

\section{RESULTS}

One hundred and twenty-one patients were assessed for eligibility for the study. Twenty-two patients were excluded, and three patients were lost to followup. Therefore, a total of 96 patients were randomly divided into two groups: 50 patients in Group 1, and 46 patients in Group 2. The mean ages of the patients in Groups 1 and 2 were $27.4 \pm 18.5$ years (range: 16-54 years) and 28.2 \pm 21.2 years (range: 15-71 years), re- spectively. The female-to-male ratios in Groups 1 and 2 were $0.9(23 / 27)$ and $0.09(4 / 44)$, respectively. The results and the comparison of outcome measures are presented in Table 1. The mean hospital stay lengths were similar for both groups $(\mathrm{p}=0.618)$.

In Group 1, an iatrogenic ileal injury occurred in one patient. The injury was overlooked during the procedure, and the patient underwent reoperation on the second post-operative day, prior to discharge, due to signs of peritonitis. During diagnostic laparoscopy, a $1 \mathrm{~cm}$ perforation was found on the antimesenteric side of the terminal ileum. The perforated ileal segment was exteriorized because of the presence of diffuse peritonitis. The patient was discharged on the eighth day without any further complications and was scheduled for stoma closure.

In Group 1, massive bleeding occurred after the insertion of the suprapubic trocar in one patient. The bleeding could not be controlled by direct compression, so the incision was enlarged, and the bleeding vessel was exposed and ligated. Four patients, one in Group 1 and three in Group 2, who developed wound infections were managed using regular wound care in the outpatient setting. Two patients, one in Group 1 and one in Group 2, with intraabdominal abscess were immediately rehospitalized. In both cases, parenteral antibiotherapy with piperacilline-tazobactam ( $13.5 \mathrm{~g} /$ day, intravenous) was started, and a percutaneous drainage catheter was inserted under sonographic guidance by an interventional radiologist.

Three patients in group one presented with paralytic ileus. Of the three, one patient was managed via enema application in the outpatient setting. However, the other two were rehospitalized and received conser-

Table 1. Results of outcome measures

\begin{tabular}{|c|c|c|c|c|c|c|c|}
\hline & \multicolumn{3}{|c|}{ Group $1(n=50)$} & \multicolumn{3}{|c|}{ Group $2(n=46)$} & \multirow[t]{2}{*}{$p$} \\
\hline & $\%$ & $\mathrm{n}$ & Mean \pm SD & $\%$ & $\mathrm{n}$ & Mean \pm SD & \\
\hline \multicolumn{8}{|l|}{ Postoperative complications } \\
\hline Wound infection & 2.1 & 1 & - & 6 & 3 & - & 0.618 \\
\hline Intraabdominal abscess & 2.1 & 1 & - & 2 & 1 & - & 0.999 \\
\hline Bleeding & - & - & - & - & - & - & - \\
\hline Paralytic ileus & 6.5 & 3 & - & - & - & - & 0.106 \\
\hline Purulent peritonitis & 2.1 & 1 & - & - & - & - & 0.479 \\
\hline Length of hospital stay (hours) & - & $12-192$ & $20.3 \pm 14.3$ & - & $8-120$ & $21.12 \pm 18.56$ & 0.618 \\
\hline Readmission & 13 & 6 & - & 8 & 4 & - & 0.513 \\
\hline Rehospitalization & 6.5 & 3 & - & 6 & 3 & - & 0.999 \\
\hline Reoperation & 2.1 & 1 & - & - & - & - & 0.479 \\
\hline \multicolumn{8}{|l|}{ Visual analog pain score } \\
\hline Postoperative 4th hour & - & $9-9$ & $8.78 \pm 1.27$ & - & $9-9$ & $9 \pm 0.54$ & 0.537 \\
\hline At discharge & - & $4-5$ & $4.74 \pm 0.8$ & - & $5-5$ & $4.86 \pm 0.81$ & 0.327 \\
\hline Quality of life score & - & $8-9$ & $8.64 \pm 0.94$ & - & $8-9$ & $8.64 \pm 0.94$ & 0.888 \\
\hline
\end{tabular}


vative treatment, including nasogastric decompression and bowel rest. Both patients were discharged on the second day.

There were no mortalities in either of the groups.

\section{DISCUSSION}

Previous studies have consistently found that the overall rate of postoperative complications, including intraabdominal abscess formation, wound infection, and paralytic ileus, is higher in complicated appendicitis, irrespective of the method used for appendectomy. ${ }^{[13]}$ Thus, the major determinant of postoperative complications seems to be related to advanced disease rather than the method of appendectomy in complicated appendicitis. Therefore, the present study focused on cases with uncomplicated appendicitis.

Early studies comparing LA and OA reported higher rates of postoperative septic complications in LA. ${ }^{[7-9]}$ However, numerous recent studies comparing LA and OA have reported contradictory results, ${ }^{[8,9]} \mathrm{al}-$ though most of the studies included a heterogeneous group of acute appendicitis cases, including all types of complicated appendicitis. Unfortunately, currently available data comparing LA and OA in uncomplicated appendicitis are limited and originate from either studies specifically focused on uncomplicated appendicitis patients or subgroup analyses from studies of patients with all types of appendicitis. Therefore, only a few studies could be used for comparison of results in the present study. ${ }^{[14-17]}$ The rates of postoperative complications in both groups were similar and were comparable to those of the previous studies.

Although shorter length of hospital stay is a wellknown advantage of minimally invasive surgery, in the present study, no hospital stay length advantage was associated with either uncomplicated appendicitis group. Moreover, regardless of the appendectomy technique, early discharge within the first 24 hours after appendectomy for uncomplicated appendicitis does not seem to lead to a significant increase in the rate of postoperative complications when compared to the results of similar studies. ${ }^{[7,9]}$

We found that postoperative pain and quality of life in both groups were similar. This conflicts with two other important advantages of minimally invasive surgery, namely, less postoperative pain and faster return to daily activities. However, it also conflicts with previous studies comparing LA and OA in terms of quality of life in both the short-term and the long-term in which better quality of life has been associated with LA. ${ }^{[18-20]}$ Preference for the laparoscopic approach over the open approach in uncomplicated appendicitis is still justified because of the important role of laparoscopic appendectomy in surgical training and patient preference for minimally invasive surgery.
In conclusion, the laparoscopic approach to appendectomy in patients with uncomplicated appendicitis does not offer a significant advantage over the open approach, in terms of length of hospital stay, postoperative pain scores, or quality of life, which are considered the major advantages of minimally invasive surgery. However, it should also be noted that concerns about increased postoperative septic complications with the laparoscopic approach in uncomplicated appendicitis seem to be unfounded.

Conflict-of-interest issues regarding the authorship or article: None declared.

\section{REFERENCES}

1. Fingerhut A, Millat B, Borrie F. Laparoscopic versus open appendectomy: time to decide. World J Surg 1999;23:835-45.

2. Semm K. Endoscopic appendectomy. Endoscopy 1983;15:5964.

3. Laine S, Rantala A, Gullichsen R, Ovaska J. Laparoscopic appendectomy-is it worthwhile? A prospective, randomized study in young women. Surg Endosc 1997;11:95-7.

4. Fogli L, Brulatti M, Boschi S, Di Domenico M, Papa V, Patrizi P, et al. Laparoscopic appendectomy for acute and recurrent appendicitis: retrospective analysis of a singlegroup 5-year experience. J Laparoendosc Adv Surg Tech A 2002;12:107-10.

5. Ortega AE, Hunter JG, Peters JH, Swanstrom LL, Schirmer B. A prospective, randomized comparison of laparoscopic appendectomy with open appendectomy. Laparoscopic Appendectomy Study Group. Am J Surg 1995;169:208-13.

6. McCall JL, Sharples K, Jadallah F. Systematic review of randomized controlled trials comparing laparoscopic with open appendicectomy. Br J Surg 1997;84:1045-50.

7. Sauerland S, Jaschinski T, Neugebauer EA. Laparoscopic versus open surgery for suspected appendicitis. Cochrane Database Syst Rev 2010;10:CD001546.

8. Asarias JR, Schlussel AT, Cafasso DE, Carlson TL, Kasprenski $\mathrm{MC}$, Washington $\mathrm{EN}$, et al. Incidence of postoperative intraabdominal abscesses in open versus laparoscopic appendectomies. Surg Endosc 2011;25:2678-83.

9. Liu Z, Zhang P, Ma Y, Chen H, Zhou Y, Zhang M, et al. Laparoscopy or not: a meta-analysis of the surgical effects of laparoscopic versus open appendicectomy. Surg Laparosc Endosc Percutan Tech 2010;20:362-70.

10.http://www.atsqol.org/sections/instruments/ko/pages/nott. html. American Thoracic Society. Nottingham Health Profile.

11. Hunt SM, McEwen J, McKenna SP. Measuring health status: a new tool for clinicians and epidemiologists. J R Coll Gen Pract 1985;35:185-8.

12. McEwan J. The Nottingham health profile. In: Walker SJ, Rosser RM, editors. Quality of life assessment: key issues in the 1990s. 2nd ed. New York, NY: Springer; 1993.

13. Gonenc M, Gemici E, Kalayci MU, Karabulut M, Turhan $\mathrm{AN}$, Alis H. Intracorporeal knotting versus metal endoclip application for the closure of the appendiceal stump during laparoscopic appendectomy in uncomplicated appendicitis. J Laparoendosc Adv Surg Tech A 2012;22:231-5.

14. Sahm M, Kube R, Schmidt S, Ritter C, Pross M, Lippert H. Current analysis of endoloops in appendiceal stump closure. Surg Endosc 2011;25:124-9. 
15. Amortegui JD, Restrepo H. Knot security in laparoscopic surgery. A comparative study with conventional knots. Surg Endosc 2002; 16:1598-602.

16. Beldi G, Vorburger SA, Bruegger LE, Kocher T, Inderbitzin D, Candinas D. Analysis of stapling versus endoloops in appendiceal stump closure. Br J Surg 2006;93:1390-3.

17. Wu HS, Lai HW, Kuo SJ, Lee YT, Chen DR, Chi CW, et al. Competitive edge of laparoscopic appendectomy versus open appendectomy: a subgroup comparison analysis. J Laparoendosc Adv Surg Tech A 2011;21:197-202.
18. Katkhouda N, Mason RJ, Towfigh S, Gevorgyan A, Essani R. Laparoscopic versus open appendectomy: a prospective randomized double-blind study. Ann Surg 2005;242:439-50.

19. Kaplan M, Salman B, Yilmaz TU, Oguz M. A quality of life comparison of laparoscopic and open approaches in acute appendicitis: a randomised prospective study. Acta Chir Belg 2009;109:356-63.

20. Kapischke M, Friedrich F, Hedderich J, Schulz T, Caliebe A. Laparoscopic versus open appendectomy-quality of life 7 years after surgery. Langenbecks Arch Surg 2011;396:69-75. 